\title{
Landscape Patterns and Legacies Resulting from Large, Infrequent Forest Disturbances
}

\author{
David R. Foster, ${ }^{1 *}$ Dennis H. Knight, ${ }^{2}$ and Jerry F. Franklin ${ }^{3}$
}

${ }^{1}$ Harvard Forest, Harvard University, Petersham, Massachusetts 01366; '2Department of Botany, University of Wyoming, Laramie, Wyoming 82071-3165; and ${ }^{3}$ College of Forest Resources, University of Washington, Box 352100, Seattle, Washington 98195, USA

\begin{abstract}
A BSTRACT
We review and compare well-studied examples of five large, infrequent disturbances (LIDs) - fire, hurricanes, tornadoes, volcanic eruptions, and floods -in terms of the physical processes involved, the damage patterns they create in forested landscapes, and the potential impacts of those patterns on subsequent forest development. Our examples include the 1988 Yellowstone fires, the 1938 New England hurricane, the 1985 Tionesta tornado, the 1980 eruption of Mount St. Helens, and the 1993 Mississippi floods. The resulting landscape patterns are strongly controlled by interactions between the specific disturbance, the abiotic environment (especially topography), and the composition and structure of the vegetation at the time of the disturbance. The very different natures of these interactions yield distinctive temporal and spatial patterns and de-
\end{abstract}

\section{INTRODUCTION}

Large infrequent disturbances (LIDs) play an important role in many forested landscapes, in part because the resulting landscape pattern influences the rate and pattern of energy flow, nutrient cycling, wildlife and human responses, and susceptibility to subsequent disturbance (Turner and Dale 1998). Recognition of the control of landscape pattern and process by natural disturbance regimes has fundamentally altered the interpretation and management of forest ecosystems (Peterken 1997). Nonetheless, despite extensive research on disturbances,

Received 14J uly 1998; accepted 6 October 1998.

*Corresponding author; e-mail: drfoster@fas.harvard.edu mand that ecologists increase their knowledge of the physical characteristics of disturbance processes. Floods and fires can occur over a long period, whereas volcanic eruptions and wind-driven events often last for no more than a few hours or days. Tornadoes and floods produce linear patterns with sharp edges, but fires, volcanic eruptions, and hurricanes can affect broader areas, often with gradual transitions of disturbance intensity. In all cases, the evidence suggests that LIDs produce enduring legacies of physical and biological structure that influence ecosystem processes for decades or centuries.

Key words: disturbance; forest ecosystem; landscape; legacy; fire; hurricane; tornado; volcano; flood; Mount St. Helens; Yellowstone fires; Mississippi River.

there have been few attempts to compare the landscape characteristics of large disturbances or the implications of regional differences in disturbance regimes for understanding forest dynamics and characteristics [cf. Rogers (1996)]. In this article, we examine five LIDs that influence forest ecosystemshurricanes, tornadoes, floods, volcanoes, and fireand we evaluate the complex landscape patterns that result from the interaction of these physical processes with the abiotic and biotic environment (Swanson and others 1990; Foster and Boose 1992). To highlight the distinctive characteristics and damage patterns of each LID, we present examples of well-studied historical events, contrasting the controls over their distribution and effect and evaluating the biological legacies that influence subsequent 
ecosystem process. By legacies, we mean physical structures (for example, sediment layers, windthrow mounds, and lava flows) and biotic remnants (for example, seeds, rhizomes, and coarse woody debris) that persist after disturbance. We argue that the specific landscape patterns and legacies of disturbance are critical to understanding the contrasting characteristics of ecosystem recovery from different types of disturbance. Furthermore, a long-term pattern of LID events comprises characteristic disturbance regimes that exert an enduring influence on the landscape-level arrangement of vegetation and ecosystem process [cf. Franklin and Halpern (1989)].

\section{HuRRICANES}

Hurricanes (known as typhoons in the western Pacific region) develop in tropical oceanic regions where warm surface water temperatures $\left(26^{\circ} \mathrm{C}\right.$ or warmer) and an atmosphere conducive to the development of cloud towers coincide with an external starting mechanism (Foster and Boose 1994). In the northern hemisphere, hurricanes often follow a parabolic path, drifting westward and poleward with the tropical trade winds and then recurving eastward with the prevailing westerlies at higher latitudes (Dunn and Miller 1964; Simpson and Riehl 1981). Hurricane season extends from June to November, with storms most common in September, when ocean temperatures are warmest. In Eastern North America, hurricane frequency and importance decrease with latitude and from coastal areasinland.

A mature hurricane is a revolving vortex (counterclockwise in the Northern Hemisphere) that extends upward $7-8 \mathrm{~km}$ and to a radius of $1000 \mathrm{~km}$. The central eye is characterized by low pressure and low wind speeds, and is surrounded at a radius of approximately $30 \mathrm{~km}$ by the eyewall, an area of intense convection where the highest wind speeds and precipitation occur (Foster and Boose 1994). Beyond the eyewall wind speeds and precipitation normally decline exponentially, such that severe wind damage sel dom extends beyond $100 \mathrm{~km}$ (Frank 1977; Anthes 1982). Hurricanes weaken upon landfall due to increased surface friction and removal of the energy source of warm, moist sea air. However, tropical storms may regain their intensity if they move back out to sea, though colder oceans diminish their power.

The patterns of damage caused by hurricane winds on forested landscapes are complex and may appear from field observations to be random and indecipherable (Webb 1958). However, studies of the interaction of meteorological, physiographic, and biotic factors provide insights on the important controlling processes (Smith 1946; Foster and Boose 1992; Boose and others 1994). Regional scale (about $100-500 \mathrm{~km}$ ) patterns of forest damage are controlled by (a) wind gradients resulting from hurricane size, intensity, and storm track; (b) large topographic features such as coastlines and mountain ranges that weaken storms; and (c) regional variation in vegetation. Landscape-scale (about 10 $\mathrm{km}$ ) patterns of forest damage are controlled by interactions among (a) gradients of wind velocity and direction and finer-scale meteorological phenomena such as gusts, downbursts, and tornadoes; (b) topographic exposure; and (c) differential stand susceptibility to wind as determined by composition, structure, site conditions, and stand history. As a consequence of such interactions, the potential range in patterns of damage and resulting landscape structure is enormous. The impact is also highly dependent on the history of natural disturbance and human activity (Foster and others 1999).

Hurricane impact across a gradient of spatial scales isillustrated by the 1938 hurricane, one of the most catastrophic windstorms in US history. At a regional scale, the storm created a pattern of variable damage across a swath $100 \mathrm{~km}$ wide and nearly $300 \mathrm{~km}$ long that extended from Long Island northward into northern Vermont (Figure 1) (Smith 1946; Foster 1988a). Damage was concentrated to the right side of the storm track, where the forward movement of the storm (greater than $50 \mathrm{kph}$ ) coincided with the rotational velocity, and damage was influenced by regional variation in forest type and extent (Foster 1988b). At a landscape scale, vegetation height and composition, controlled in large part by prior land use, interacted with wind exposure determined by slope, aspect, and landscape position to produce a patchy damage pattern characterized by a highly irregular border (Foster and Boose 1992). At the stand scale, uprooting was a predominant mode of windthrow, with the intensity of damage strongly correlated with tree height and species (Foster 1988a). Conifers were much more susceptible than hardwoods. The resulting pattern was highly variable at all scales, with small individual and multiple tree gaps and branch breakage occurring along with extensive windthrow over large areas [cf. Naka (1982)].

Hurricanes produce many important and longlasting legacies, including a patchwork of forest age and height structure, uproot mounds and downed boles, standing broken snags, and leaning and damaged trees (Foster 1988a). The survival, releafing, and sprouting of windthrown and damaged trees may provide important biotic control on subsequent 


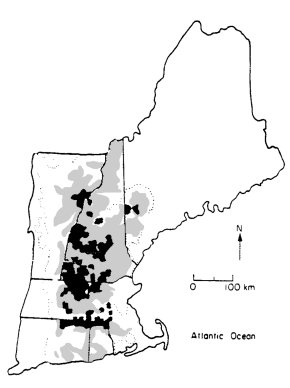

Hurricane (1938 New England)

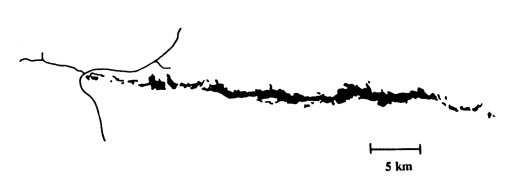

Tornado (Tionesta Scenic Area)

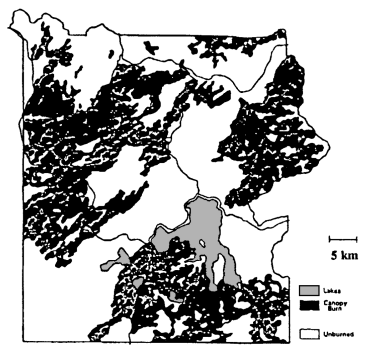

Fire (Yellowstone National Park)

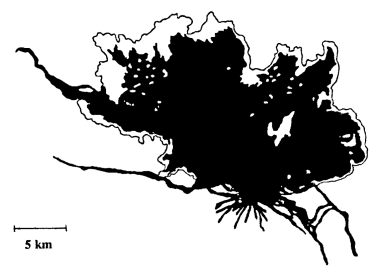

Volcano (Mount St Helens)

Figure 1. Landscape and regional scale patterns of forest disturbance resulting from five contrasting large infrequent disturbances: the 1938 Hurricane in New England, the Yellowstone fires of 1988, the eruption of Mount St. Helens in 1980; the tornado at the Tionesta Scenic Area in Pennsylvania, and floods in the Mississippi River in 1993. The areas of greatest disturbance are shown in black. Lesser disturbance is shown in grey.

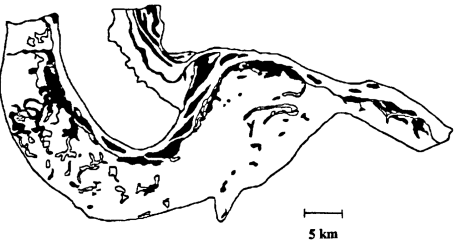

Flood (Mississippi River)

ecosystem development (Foster and others 1997; Scatena and others 1997; Zimmerman and others 1997). Also, increased loadings of fine woody debris and leaves may increase the probability of fire and multiple LIDs in the same area (Patterson and Foster 1990; Lynch 1991; Paine and others 1998). Floods and landslides resulting from the intense and extended precipitation that may accompany hurricanes can have additional profound effects on ecosystem processes and trophic structure (Scatena and Larson 1991; Covich and others 1997). The soil legacies created through tree uprooting and landslides triggered by windthrow and intense precipitation are an inherent part of soil dynamics and landscape pattern in many landscapes (Stephens 1956), and exert a strong, though fine-scaled, control over patterns of regeneration and variation in biogeochemical processes (Bowden and others 1993; Carlton and Bazzaz 1998).

The meteorological and oceanic controls over tropical storm frequency and intensity interact with coastline geography to produce strong variation in hurricane disturbance regimes along coastal regions of the Atlantic and Pacific, including striking differences among relatively adjacent locations. In the Caribbean, some locations experience intense and slow-moving storms with such frequency that hurricanes may be considered essentially a chronic disturbance and the vegetation is continually recovering from windthrow (Lugo and Scatena 1989), whereas in northern latitudes powerful storms may occur at century or longer intervals. In many hurricaneprone areas, the long-term consistency in storm movement and the direction of intense winds may interact with topography to produce persistent land- scape-level patterns of vegetation (structure and composition) and legacies of hurricane disturbance (Foster and Boose 1994).

\section{TORNADOES}

Tornadoes are among the most violent and unpredictable of meteorological phenomena and, as shortlived, relatively small, and complex storms, they are difficult to study directly, impact limited areas, and have a very long return interval (Fujita 1971; Peterson and Pickett 1991). A tornado is a relatively orderly, though violently rotating, column of air in which the azimuthal velocity drops off rapidly with distance from the center of the vortex. At ground level, the air converges rapidly into the funnel, often creating a convergent pattern of damage and giving the wind tremendous lifting and moving capability. Tornado winds greatly surpass hurricane winds in intensity, reaching an estimated maximum exceeding $400 \mathrm{kph}$ [F5 on the Fujita scale (Fujita 1987)].

Tornadoes develop under three meteorological conditions that control their geographical, seasonal, and diurnal distribution. The largest and most damaging tornadoes, and the most extensive clusters of tornadoes, are spawned in long-lived supercell thunderstorms. Isolated tornadoes may also develop in ordinary thunderstorms, and small clusters of tornadoes are frequently produced in the right-front quadrant of hurricanes following landfall (Bluestein 1996). Supercell thunderstorms are highly organized meteorological systems with an intense, rotating updraft that can produce a series of mesocyclones, each of which is capable of generating a 
tornado that may develop through a five-phase cycle: (a) dust-whirl stage, when dust movement indicates cyclonic circulation from the cloud to the surface; (b) organizing stage, as condensation from lowered air pressure fills the expanding funnel; (c) mature stage, when the funnel reaches peak size and intensity and a near vertical orientation; (d) shrinking phase, when the funnel decreases in diameter and begins to tilt; and (e) decaying stage, when the vortex shrinks and becomes ropelike. Due to their association with supercell thunderstorms and formation at the boundary between relatively moist maritime and dry warm continental air masses, tornadoes are most common in spring in late afternoon and are concentrated in interior continental re gions, decreasing toward the coasts (Fujita 1987).

Tornado funnels move with the associated weather system, which in North America is predominantly to the northeast (59\%) and east (19\%). Violent storms (F5) have an even greater tendency (72\%) to follow a northeasterly direction (Fujita 1987). Tornadoes are extremely variable in intensity, path length, width, and continuity. Fujita (1987) has documented a very strong positive relationship between the path length or area impacted and wind speed, with F0 (65-115 kph) storms having a mean path length of $1.9 \mathrm{~km}$ compared with $60 \mathrm{~km}$ for F5 storms (350-510 kph). Funnel movement and storm characteristics such as intensity and width depend on atmospheric and meteorological conditions. Thus, in contrast to hurricanes, tornado impact is not strongly related to physiography or vegetation (Grazulis 1993). Due to this extreme variability in individual storms, the potential for multiple touchdowns, and the high frequency of multiple storms in clusters, tornadoes can create complex damage patterns. The great range in storm intensity leads both tornadoes and hurricanes to create gradients of damage ranging from branch break and single tree gaps to extensive areas of complete blowdown. Unlike hurricanes, tornadoes are not generally accompanied by extensive rainfall or flooding and, due to the extremely long return interval to any particular location, the concept of disturbance regime is much less useful.

Tornadoes are often associated with, and confused with, downbursts and microbursts, which can generate very similar patterns of landscape damage (Fujita 1971; Grazulis 1993). Downbursts are strong downdrafts of air from a thunderstorm or large cumulus cloud that generate an outflow of wind that travels in straight or curved lines outward from the point of ground initiation, in contrast to the often convergent pattern of tornado winds (Grazulis 1993). Downbursts exhibit an extreme range in size from less than $50 \mathrm{~m}$ to greater than $10 \mathrm{~km}$ in width (microbursts, less than $4 \mathrm{~km}$ in width; macrobursts, more than $4 \mathrm{~km}$ in width). Downbursts caused extensive damage to old-growth forests along Flambeau River in Wisconsin (Dunn and others 1983) and in the Five Ponds Wilderness Area of the Adirondacks in New York. At Five Ponds, the damage extended across an area exceeding 20,000 ha and included widespread blowdown in the typical straight-line downburst pattern [cf. Grazulis(1993)].

The tornado "outbreak" of May 31, 1985, that impacted Pennsylvania, Ohio, New York, and Ontario illustrates the landscape pattern and ecological impact of severe tornadoes (Peterson and Pickett 1995). The outbreak was the worst in the history of the region and was comprised of 41 separate tornadoes, including eight of category F4 and F5 that killed 42 people and injured 1047 (Grazulis 1993). Impact was concentrated between Lake Ontario and Lake Huron, with tracks oriented eastward and northeastward (Figure 1). More than $800 \mathrm{~km}$ of tornado damage was mapped, with an average path width of $500 \mathrm{~m}$ and range from less than $200 \mathrm{~m}$ to more than $2750 \mathrm{~m}$. The F4 tornado at the Tionesta Scenic Area had a path length of more than $19 \mathrm{~km}$ and width exceeding $1 \mathrm{~km}$, and it blew down substantial areas of second-growth and old-growth forest. The damage pattern within the old-growth area was remarkable for the sharpness of the edge between intact forest and completely windthrown areas (D. Foster unpublished data; Peterson and Pickett 1995). Uprooted and broken trees were arranged in both convergent and divergent patterns with wide variation in orientation. The absence of physiographic or biotic control was indicated by damage across all slopes and aspects. Thus, with regard to the factors controlling landscape pattern, the sharpness and extent of the damage pattern, and the spatial orientation of the damage, these tornadoes were strikingly different from the 1938 hurricane. Notably, at a stand level the biological and physical legacies in intensively damaged areas were quite similar for both storms (Foster 1988a; Peterson and Pickett 1995).

Hurricanes, tornadoes, and downbursts represent extremes in the gradient of size and severity of wind damage. In many regions, however, other meteorological phenomena, including frontal storms, can approach such magnitudes (Swanson and others 1988). In addition, all storm types have a gradient of intensities and many individual storms vary greatly during the course of their evolution in terms of severity and spatial extent of damage. Most ecological studies emphasize broad-scale and catastrophic effects (Yih and others 1991). However, the major 
role of tropical storms and tornadoes as lowintensity (for example, gap-forming) eventsisimportant, though often overlooked (Bormann and Likens 1979; Naka 1982; Shaw 1983).

\section{FIRES}

Fires typically are caused by lightning and humans, and they generally burn less than a few hectares before they are extinguished because of rain, a fuel complex that is not sufficiently flammable, or suppression by human activities. However, during long periods of drought and strong winds, fires can burn out of control, sometimes for months and over millions of hectares. Therefore, like tornadoes, hurricanes, and floods, they are a climatically driven disturbance. In northern and montane conifer forests, large, infrequent fires account for less than 3\% of all fires, but more than $95 \%$ of the land area burned (Agee 1993). Such fires are important (or were important before suppression) in the coniferous and mixed conifer-hardwood forests of northern Eurasia and northern and western areas of North America, leaving an irregular, long-lasting mosaic of burned and unburned vegetation (Knight 1987; Heinselman 1996). The return interval for large, infrequent forest fires varies from about 70 years to over 300 years (Hemstrom and Franklin 1982; Foster 1983; Whelan 1995). Forest structure may be abruptly changed by intense canopy fires, which burn leaves and small branches and which are accompanied by surface fires that consume forest floor and understory vegetation. Notably, most of the larger tree boles are not burned, even if killed, and they often remain standing for 10-50 years after a fire. Such snags and residual living and dead organic matter are enduring legacies of fire that are important for wildlife habitat, nutrient dynamics, ecosystem function, and forest recovery (Harmon and others 1986).

The spread of fire across a landscape involves the drying of fuels and the production of gases (pyrolysis) that are ignited and burned in visible flames, a processknown as flaming combustion (J ohnson 1992; Agee 1993; Whelan 1995). The flaming front moves most rapidly (up to $10 \mathrm{kph}$ ) with strong winds because the flames are pushed closer to the unburned fuels ahead. After flaming combustion has ignited and burned most of the volatiles in the fuel base, the remaining carbon is subjected to glowing combustion, a process that is much slower, is not easily extinguished, and enables the fire to continue burning for several days or weeks, even in damp weather. As the hot air rises, cooler air is drawn into the base of the flames, providing oxygen. This upward air movement, combined with the additional turbulence created by winds, often carries glowing embers to new points of ignition, a process known as spotting. Thus, although a fire starts at one place, it spreads by flaming combustion, glowing combustion, and spotting. Moreover, multiple ignitions are likely to occur when climatic conditions are favorable. If not extinguished, the spread of a single fire occurs at variable rates, often shifting directions as the prevailing winds change (Foster 1983). The pattern of a burned area will be more linear if there have been only a few ignition points and strong directional winds.

Because of the upward movement of hot air, flames burn uphill more readily than down. Therefore, leeward slopes often burn with less intensity, if they burn at all, illustrating one way that topography influences fire and the postfire landscape pattern that develops. Ridges can function as firebreaks, along with rivers, lakes, and areas of lessfuel or less flammable fuels [ for example, see Melanson and Butler (1984), Foster and King (1986), and Grimm (1984)]. The abundance of fuel may affect fire spread when conditions contributing to flammability are not extreme, but high-intensity firestorms (crown fires, or wildfires) will typically burn a larger portion of the landscape more evenly. For example, young as well as old forests burned during the 1988 "firestorms" in the Greater Yellowstone area, which occurred primarily during the drier, windier period of late summer. Even then, however, some tracts of forest were not burned, creating an irregular landscape mosaic (Figure 1) (Christensen and others 1989). As the intensity of a fire lessens during the evening when wind is low and humidity is high, on leeward slopes, or at the edge of a burn, the proportion of trees and other plants that are killed is reduced. Thus, the perimeter of fires typically has a diffuse border, where some of the trees are killed and some survive. Trees that survive but are damaged or scarred may be more susceptible to insects and fungi (Gara and others 1984), illustrating how fires can lead to secondary effects on vegetation dynamics. The complex of dead trees, organic matter, and surviving organisms, and the pattern of variable-sized patches of unburned vegetation and areas of different burn intensity, comprise the legacies of fire that are so important in diversifying forest landscapes(Heinselman 1973; Swanson 1981). Variation in fire size, intensity, type, and return frequencies as controlled by weather, vegetation, and the distribution of firebreaks produces characteristic fire regimes that vary on a broad scale. In turn, these contrasting regimes produce distinctive longterm patterns in forest age and height structure, 
composition and the distribution, and abundance of fire-generated legacies such as standing dead trees, coarse downed debris, and charcoal.

\section{FLOODS}

Floods occur when the rate of water supply exceeds the capacity of stream-channel drainage. Such conditions develop during periods of heavy rains and rapid melting of snow and ice, making most floods a climatically driven phenomenon. Other floods occur when dams break, whether the dams are constructed by humans or were caused by ice jams, landslides, or beavers, or by tectonic and other geological processes, including volcanoes. In narrow, upper-watershed streams, floods can exert a pronounced geomorphic impact that may shape local landscapes, vegetation patterns, and ecosystem function for decades (Baker and others 1988). However, in large, lower-watershed rivers, the long history of regular flooding is indicated by the presence of geomorphically and vegetationally distinct floodplains, and floods play a fundamental role in the maintenance and function of the "riverfloodplain" ecosystem (Bayley 1995; Sparks 1996; Bornette and Amoros 1997). Notably, aside from severe economic damage to buildings, roads, bridges, and cropland that were developed with inadequate regard to the inevitability of floods, the ecological damage of regular flooding may be minor. Floodplain plants and animals are well adapted to periodic inundation, and consequently riverine ecologists agree that most "flood pulses" should not be viewed as a disturbance (Bayley 1995). Indeed, many organisms in the river and on the floodplain depend on floods (for example, many species of fish for spawningand plantsfor continued establishment on deposits of nutrient-rich sediment). Typically, the mechanical force of floodwater is not adequate to increase plant mortality rates, especially when flooding occurs in spring before leafout of deciduous trees. Geomorphic processes such as oxbow formation, ice scouring, and bank erosion may cause the death of some trees and changes in the landscape mosaic, but vegetation structure and resource distribution are generally affected only over limited areas. Considering the range of benefits that floods can bring to river-floodplain ecosystems, the major disturbance to many river ecosystems is flood suppression (Williams and Wolman 1984; Bayley 1995).

Exceptional events such as the great floods of 1993 in the Mississippi River drainage system (primarily the lower Mississippi, Illinois, and Missouri Rivers) may create extensive, though highly variable, damage patterns (Figure 1). Tree mortality following the 1993 event was widespread, reaching $50 \%-90 \%$ in some areas. The primary cause of mortality was excessively long periods of inundation during the middle of the growing season that killed the roots of many species due to the development of anaerobic conditions. As noted by Sparks (1996), some mortality may result, paradoxically, from drought stress due to the inability of the depleted or damaged roots to replace the transpired water. Thus, a flood-caused disturbance can be highly selective, with severity related to flood duration, geomorphology, species composition, and speciesphysiology (Sparks 1996). Slightly higher ground on the floodplain, such as that of older terraces, would have shorter periods of inundation, and thus it is not surprising that topography is often correlated with the mosaic of stands with high and low plant mortality (Sparks 1996). The constrained nature of river-floodplain ecosystems leads to smaller and more linear disturbed areas than following large fires and hurricanes. However, the kinds of floods that cause disturbances typically last for months, like large fires, rather than minutes or hours (as is the case with volcanic eruptions, tornadoes, and hurricanes).

\section{Volcanic ERUPTIONS}

Volcanic eruptions are usually complex events that span a wide gradient of intensity, size, and duration and involve the interactions of multiple disturbances, including explosive blasts, thermal and toxic chemical waves, landslides, glowing avalanche deposits, debris flows (lahars), lava flows, and airfalls of volcanic ejecta (tephra). Each disturbance type has unique attributes with regard to impact, spatial characteristics, interactions with existing landforms, and resultant landscape-level patterns. Interactions between these disturbance types are important in determining the nature of the postevent landscape. Geographically, volcanic activity is strongly controlled by tectonic processes such as occur along the Pacific Rim of western North America. Earthquakes, another consequence of the tetonic activity characteristic of this region, also produce widespread geomorphic changes that are critical to the understanding of forest growth and patterns (Veblen and others 1992).

Eruptive-related disturbances can be very large (for example, 1,000,000 $\mathrm{km}^{2}$ or more), particularly in the case of airfall depositions, although a scale of $10-1000 \mathrm{~km}^{2}$ is more common. Patterns are typically either isodiametric, where there is an epicenter for the disturbance, such as with an explosive blast, or linear to dendritic where a flow is involved, such 
as with a landslide or lava flow. Edge definition varies widely but is generally most abrupt with the most intense disturbances, such as glowing avalanches. Volcanic disturbances tend to be short term and high intensity, although debris flow and airfall deposition vary substantially in intensity and most exhibit severity gradients related primarily to distance from source. Volcanic disturbances interact with and are influenced by physiography and existing ecosystem conditions to varying degrees, and thus prediction of landscape patterns is moderate to high for volcanic disturbances (given a known point of origin and magnitude of the event). Flow-type disturbances are most predictable because of topographic controls on their direction and boundaries. Airfall depositions are least predictable because of their dependence upon wind speed and direction in the upper and lower atmosphere. A unique and important characteristic of volcanic eruptions is their lack of seasonality and predictability of return interval. Furthermore, seasonal timing of the eruptive event has a very profound effect on its impacts and the resulting postdisturbance landscape pattern.

The eruption cycle of Mount St. Helens that began on 18 May 1980 provides a well-studied example of at least seven volcanic disturbance types (Figure 1). Initiated with a series of small explosions and minor airfall deposition during early 1980, a landslide on 18 May unroofed the core of the volcano and led to a blast and thermal wave that created a roughly semicircular "blast" zone. Glowing avalanchessubsequently occurred on the mountain itself, and debris flows occupied major drainages. Tephra fell on hundreds of thousands of square kilometers, but magma was extruded only within the exposed mountain crater. Thus, unlike the familiar tectonic processes in Hawaii, lava flow was insignificant. The blast zone was subjected to at least three different disturbances types-explosive blast, thermal wave, and tephra deposition-and some areas, such as drainages, were subjected to up to threeother disturbancetypes-landslide, debrisflow, and glowing avalanche deposit. Topography was an important factor influencing the distribution and intensity of gravity-based events, such as the landslide, mudflows, and glowing avalanches. Topography had less effect on the explosive blast, although mountaintops and ridges provided protection for some locations and influenced the patterns of tree blowdown.

Biological legacies were present throughout most of the blast zone despite the intensity and multiplicity of disturbance events (Franklin and others 1985). Surviving animals, perennating plant parts, and other bel owground organisms varied widely in abundance after the eruption. None were associated with glowing avalanche deposits; few on the landslide deposits along the margins of the flow; moderate abundance associated with debris flows; and great abundance on the blast zone. Most surface waters within the blast zone also retained many fish, amphibians, and plankton. Death of organisms in the areas subjected only to tephra deposition was generally selective and left the structure and function of the affected ecosystems relatively intact.

The combined effects of predisturbance landscape patterns, multiple disturbances, physiography, and varying levels of biological legacies resulted in very complex spatial patterns within the blast zone. For example, rapid recovery of vegetation on recently clear-cut areas contrasts with slow recovery of areas occupied by virgin forests (Franklin and others 1985; Franklin and Hal pern 1989). Similarly, organisms within persistent late-spring snowpacks were protected from the blast and development of a hard tephra crust. Overall, the presence of residual organisms ensured that recovery within the large blast zone developed from many well-distributed foci rather than through recolonization from the margin. The importance of the seasonal timing of the Mount St. Helens event is clear. A comparable eruption during midwinter with a deeper, more widespread snowpack would have greatly extended mudflows and would have provided a protective cover for more of the blast zone, whereas a similar event during the late summer would have had reduced mudflows and snowbank refuges. Significantly different posteruptive landscapes would result, depending on the season of eruption.

\section{COMPARISON OF LIDS IN FOREST LANDSCAPES}

The complexity of disturbance patterns resulting from LIDs has led to their characterization as random, chaotic, and uninterpretable (Shaw 1983). However, an understanding of their interactions with the physical structure and biological characteristics of the landscape greatly enhances our ability to interpret and characterize the patterns of disturbance, to reconstruct their occurrence, and to predict their distribution in time and space (Fujita 1987; Arno and others 1993; Boose and others 1994). Notably, this approach has led to the recognition that variation in the landscape-level distribution of disturbance type and intensity helps to explain spatial patterns of ecosystem structure and function (Foster 1983; Grimm 1984; Lugo and Scatena 1989; M otzkin and others 1996). Over long 
Table 1. General Characteristics of the Large Infrequent Disturbances (LIDs) Discussed in This Paper

\begin{tabular}{llllll}
\hline & Volcanic & & Forest & & Rivervine \\
LID Characteristic & Eruptions & Tornadoes & Fires & Hurricanes & Floods \\
\hline Duration of event & Hours & Minutes & Weeks/months & Hours & Weeks/months \\
Return interval (years) & $100-1000$ & $100-300$ & $75-500$ & $60-200$ & $50-100$ \\
Size of event $\left(k^{2}\right)$ & $5-100$ & $5-100$ & $50-20,000$ & $50-100,000$ & $50-50,000$ \\
Geographic location & Volcanic mts & Inland & Inland & Warm coasts & Riparian \\
Spatial predictability & High & Low & Moderate & Moderate & High \\
Temporal predictability & Moderate & Low & Moderate & Moderate & Moderate \\
Energy point source or flow & Variable & Flow & Flow & Flow & Flow \\
Multiple initiations & No & Yes & Yes & No & Yes \\
Cause of disturbance & & & & & \\
Burning & Localized & No & Extensive & No & No \\
Intense heat & Extensive & No & Extensive & No & No \\
Inundation (flooding) & Localized & no & No & Localized & Extensive \\
Strong wind & No & Yes & Periodic & Yes & No \\
Landslides & Localized & No & Localized & Localized & Bank erosion \\
Explosive blast & Extensive & No & No & No & No \\
Glowing avalanche & Localized & No & No & No & No \\
Debrisflow & Localized & No & No & No & Periodic \\
Lava flow & Extensive & No & No & No & No \\
Toxic chemicals & Extensive & No & No & No & No \\
Airfall deposition & Variable & No & No & No & No \\
Variables affecting severity & & & & & \\
Distance from energy source & Yes & Yes & Yes & Yes & Yes \\
Climatic factors & No & Yes & Yes & Yes & Yes \\
Season & Yes & Yes & Yes & Yes & Yes \\
Topographic factors & Yes & No & Yes & Yes & Yes \\
Vegetation structure & Yes & No & Yes & Yes & Yes \\
\hline & & & & &
\end{tabular}

periods, the established disturbance regime of LIDs in a region may be instrumental in determining the landscape patterns of forest stands and processes that characterize a regime. Thus, an understanding of specific disturbance events and the legacies that they create, coupled with information on the characteristic distribution of these events in time and space, is critical in the interpretation of forest landscape patterns (Table 1).

The physical characteristics of a disturbance type and the nature of an individual event clearly establish the initial limits set on the spatial extent, pattern, and temporal distribution of damage. Important attributes include the climatic and meteorological constraints on the process, the extent and manner in which damage is controlled by predisturbance vegetation and physiography, and variation in the duration, intensity, and types of disturbance effects. The geographical distribution of the LIDs that we have discussed islargely determined by their controlling meteorological drivers, for example, supercell thunderstorms for tornadoes, warm oceans and cloud towers for hurricanes, drought and lightning for natural fires, and extreme precipitation and runoff for floods. In turn, these connections between many LIDs and broad-scale weather patterns may impose constraints on subsequent landscape patterns. Thus, tornadoes move with thunderstorms in prevailing frontal systems and tend to form west-to-east damage tracks in North America (Fujita 1987). Atlantic hurricanes have a northwesterly movement that combines with their dependence on warm surface water and counterclockwise rotation to produce a decreasing gradient of damage inland from the eastern US coast and generate strongest winds from the right-hand (easterly) side of the storm (Foster and Boose 1992). Even on relatively small islands such as Puerto Rico, this northwesterly tracking and the decline in wind intensity over land has led to historical gradients of hurricane impacts that control canopy structure and forest composition (Scatena and Larsen 1991; Boose and others 1994). Of the LIDs reviewed, only volcanoes are independent of climate, although their patterns of impact and vegetation recovery may be quite sensitive to seasonal timing. 
Climatic control also constrains the seasonal occurrences of many disturbances, for example, hurricanes to August to November, tornadoes to J uly and August, floods to the season of precipitation or snowmelt, and fires to periods of low fuel moisture. Seasonal timing, in turn, controls the potential range of impact. For example, hurricanes and tornadoes generally occur during the growing season when the presence of leaves makes trees more susceptible to blowdown. However, the occasional late-season storms that occur after leaf fall in temperate areas exert quite distinctive effects, including differential damage to evergreens and a lack of major organic and nutrient inputs from massive leaf fall. Other interesting interactions occur between the seasonal timing of an LID and the physiological state of the vegetation or seasonal nature of the landscape. Volcanic impact may be strongly influenced by the presence and distribution of a snowpack, flooding by the physiological condition of the inundated trees, and fire by the microclimate and fuel-moisture conditions controlling seasonal leafout. Such seasonal effects can result in contrasting impacts and patterns of ecosystem dynamics following similar disturbances. Climatic control over disturbance regimes and subsequent ecosystem response yields strong variability in disturbance frequency and long-term patterns of ecosystem processes through cyclical and longer-term meteorological changes. Thus, Atlantic hurricane frequency has undergone multidecadal cycles associated with changes in weather on and adjacent to Africa, and a recent increase in Pacific tropical storms has been linked to ENSO activity and warming of near coastal waters. Over longer periods, natural or humangenerated changes in climate will certainly drive major changes in fire, hurricanes, and tornadoes. Due to the longevity of trees and the persistent legacies of disturbance in a landscape relative to the rate of climate change, it is likely that many landscape patterns of forest conditions and structures in a landscape have arisen as a consequence of a disturbance regime that differs from that prevailing today.

LIDs vary considerably in the nature and extent of interaction with physiography and vegetation. In turn, the degree of interaction exerts a strong influence over the predictability of the resulting damage patterns and the extent to which long-term patterns in landscape-level vegetation emerge as a consequence of LIDs. Tornadoes are unique in the near absence of topographic control, as they may impact all slopes and aspects in their erratic path. In contrast, the broad landscape-level patterns of hurricane impact appear to be explained by relatively simple exposure relationships between slope, aspect, and wind direction (Foster and Boose 1992; Boose and others 1994), and flood duration is directly related to elevation and drainage position (Sparks 1996). Topography and landform (for example, lake and wetland) distribution control the movement, intensity, and landscape pattern of fire (Heinselman 1996). Complexity emerges, however, in the case of multiple disturbance types associated with an LID, for example, gusts, tornadoes, or downbursts that may accompany a hurricane, or major shifts that occur in wind direction during a fire. Similarly, volcanic activity produces explosive blasts, thermal waves, and landslides that may be very sensitive to site exposure, whereas tephra deposition is independent of physiography.

Predisturbance vegetation may influence the behavior of a disturbance, such as fire, and with little exception influences the severity and type of damage. In particular, because of the "top heavy" nature of trees, and the lateral loading pressure generated by many LIDs, there is a tendency for damage to increase with tree age and height (Foster 1988b). Fire probability often increases with stand age due to the general increase in fuel (Clark 1989; Heinselman 1973), but individual tree suceptibility to damage or mortality from fire often declines with tree size due to increasing bark thickness and a separation of foliage from the ground, which reduces the likelihood of crown fires. Specific damage patterns following fire are determined by structural characteristics of the trees and vegetation and may vary widely within and between regions and forest types (Heinselman 1996).

LIDs differ in duration, ranging from minutes to hours for tornadoes, hurricanes, and (some) volcanic eruptions, to months or even longer for some floods, fires, and volcanic lava flows (Figure 2). The long duration of some fires enables fire changes in intensity and direction. Wind shifts may cause complex fire patterns that do not follow topography, as a leeward slope on one day becomes a windward slope on the next. In contrast, brief fires driven by one wind direction may generate narrow, linear patterns. Flood duration often is correlated with severity, as the primary cause of mortality is the extended lack of oxygen caused by long-lasting floodwaters. Tornadoes, fires, and floods commonly have multiple initiations with numerous events occurring simultaneously in relatively small areas under favorable climatic conditions. Moreover, the landscape patchiness that develops among tornadoes and fires is due, in part, to their tendency to jump from place to place, by funnel skipping and spotting, respectively. 


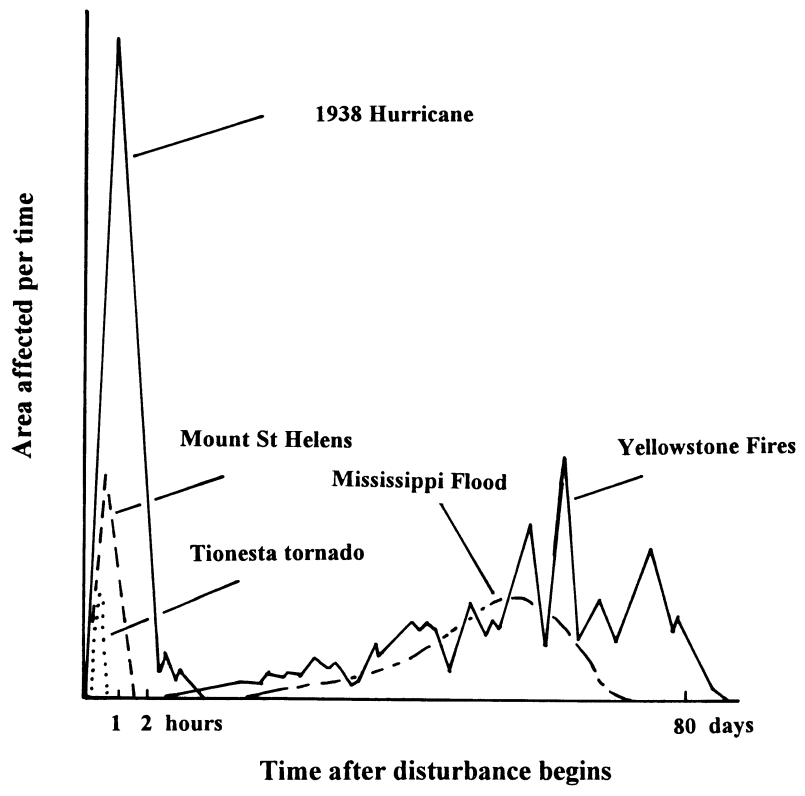

Figure 2. Comparison of the extent and duration of large infrequent disturbance by fire, flood, hurricane, tornado, and volcano.

Considerable variation exists in the area and pattern of damage resulting from different LIDS (Figure 1). In general, however, large disturbances do not create large homogeneous patches of damage. Rather, due to the aforementioned interplay of biological and physiographic factors and disturbance processes, the resulting damage tends to be heterogeneous in terms of internal patterns of mortality and landscape patterns of damage patches (Turner and Dale 1998). With the exception of tornadoes, undamaged patches are typically located within the perimeter of the disturbance, and there is a tendency for the overall pattern to be elongated in the direction of damage flow.

The number, size, and distribution of unaffected patches within a severe disturbance are of interest because of their potential impact on a variety of ecosystem characteristics. Intense tornadoes typically leave only severely impacted patches. Volcanoes, such as Mt. St. Helens, often leave few intact patches, mostly on the perimeter of the blast zone. Fires and hurricanes often leave large intact areas, as controlled by firebreaks and windbreaks and vegetation structure. In general, although hurricanes have the potential for impacting extremely large areas with severe damage, patches of intermediate damage and broad areas with scattered canopy gaps usually predominate within the damage area. The greatest number and extent of minimally disturbed patches revealed in our review was created by the 1993 floods on the Mississippi River in which broad forest areas were only thinned by extended inundation.

\section{Biological Legacies of Large INFREQUENT DISTURBANCES}

Remnants of the previous forest ecosystem, that is, biological legacies, persist following a disturbance regardless of whether the event is large or small, frequent or infrequent (Franklin and Hal pern 1989). For example, following fires, a large amount of unburned material remains, including seeds, large wood in the form of snags and coarse debris, and underground plant parts that often replace the aboveground biomass that was burned. Similarly, following hurricanes, tornadoes, and floods, most of the biomass remains in redistributed accumulations and is essential to the process of ecosystem recovery (Peterson and Pickett 1991; Cooper-Ellis and others forthcoming). Of the various disturbances, volcanic eruptions have the potential of leaving the least amount of residual material from the previous ecosystem. The intense force of the blast, and the large amount of earth that is either moved or covered with various kinds of ejecta, lead to a disturbance that is more severe than the hottest fire or the most intense windstorm. Of course, the effects diminish as distance from the volcano increases. Notably, whereas fires, windstorms, and floods move across the landscape according to the spread of heat, wind, and water, the force of volcanic eruptions is a combination of an intense pressure wave combined with scorching and the subsequent flowing of various earthen materials (including water if a large snowpack is present at the time).

The question remains whether or not LIDs lead to different legacies than smaller, frequent disturbances. Several factors must be considered. First, if the disturbance is frequent enough, then organisms comprising the ecosystem will be adapted to survive the disturbance and little change may occur. Examples would include fires that occurred at 1- to 5 -year intervals in the native grasslands of North America and floods of decadal intervals. In both cases, changes in ecosystem structure and function are so minor that a disturbance is hardly indicated. Of the LIDs examined for this article, the 1993 floods on the Mississippi River appear to have had the least amount of damage and may be inappropriately included in the LID category, despite their severe effects on human structures. In contrast, the return interval of large fires, such as the 1988 Yellowstone fires, or major windstorms and volcanic eruptions, is sufficiently long and the impact is so great that they almost invariably lead to clear changes in ecosystem structure and function. 
Table 2. Landscape Pattern Characteristics Resulting from Five Specific Large, Infrequent Disturbances (LIDS)

\begin{tabular}{|c|c|c|c|c|c|}
\hline $\begin{array}{l}\text { LID } \\
\text { Characteristic }\end{array}$ & $\begin{array}{l}\text { M ount St. Helens } \\
\text { Volcanic Eruption }\end{array}$ & $\begin{array}{l}\text { Tionesta } \\
\text { Tornado }\end{array}$ & $\begin{array}{l}\text { Yellowstone } \\
\text { Fires }\end{array}$ & $\begin{array}{l}\text { Hurricane } \\
1938\end{array}$ & $\begin{array}{l}\text { Mississippi } \\
\text { River Floods }\end{array}$ \\
\hline Year of occurrence & 1980 & 1985 & 1988 & 1938 & 1993 \\
\hline Duration of event & $12 \mathrm{~h}$ & $1 \mathrm{~h}$ & 90 days & $8 \mathrm{~h}$ & $<90$ days \\
\hline Time of year & 18 May & 31 May & May-October & September & June-August \\
\hline Overall shape ${ }^{a}$ & Isodiametric, broad & Linear, narrow & Broad & Linear, broad & Linear, narrow \\
\hline Edge transition & Diffuse & Abrupt & Diffuse & Diffuse & Diffuse \\
\hline $\begin{array}{l}\text { Minimally affected patches } \\
\text { Distribution } \\
\text { Severely affected area }\end{array}$ & Distant from crater & None & Throughout & Ridges; near edges & Throughout \\
\hline Proportion of trees killed & $100 \%$ & $50 \%$ & $85 \%-100 \%$ & $50 \%$ & $65 \%-50 \%$ \\
\hline
\end{tabular}

aShape varies with the different causes, for example, the explosive blast at M ount St. Helens led to a broad, isodiametric shape, while glowing avalanches and debris flows led to a moreliner shape (see Figure 1).

We have not identified the size that is required for a disturbance to be classified as an LID, but unlike the 1938 hurricane, the Yellowstone fires, the Tionesta tornado, or Mount St. Helens, some infrequent disturbances affect just a few hectares. The landscape pattern of legacies from small disturbances probably is of much less significance because no portion of the disturbed area is far removed from the adjacent, undisturbed portion of the ecosystem. The proximity of the undisturbed land leads to a comparatively rapid recovery. The shape of a disturbance is another landscape variable that seems especially important in determining the role of biological legacies and patterns of ecosystem recovery. If a large disturbance can be characterized as long, narrow, linear, or dendritic, as usually in the case with windstorms and floods (including volcanic debris flows some distance away from the blast zone), then ecosystem recovery will be comparatively rapid because, as with small disturbances, all portions of the disturbed area will be in close proximity to undisturbed remnants at the edges of the disturbance. Moreover, the amount of biological material remaining after windstorms and floods is larger than after fires and some volcanic eruptions, where combustion occurs.

Slower rates of recovery can be expected if the shape of a disturbance is both large and circular, as occurs following volcanic eruptions and some fires. Circular or oval disturbances seem to result from either an extraordinarily intense force, such as an isodiametric volcanic blast, or a disturbance of long duration, such as fires in western coniferous forests where the flames often burn first in one direction and then another as the wind shifts. Two other factors that surely contribute to oval-shaped burns are extreme fuel flammability and the multiple ignitions that occur during unusually dry years, such as in 1988 in the Yellowstone areas.

In a large disturbed area, the degree of patchiness is a factor influencing ecosystem recovery. Patchiness within the disturbed area probably increases as the severity of the disturbance declines or as topographic diversity increases. Long-lasting fires will burn some days with great intensity, leaving few patches as a legacy, but will burn more slowly on other days or during the night (because of cooler temperatures or less intense wind). The result is that even fires that are perceived as highly dangerous and severewill leave unburned patches. Such patchiness is less likely to develop during a volcanic eruption, as the heat and intensity of the blast destroys much of the ecosystem regardless of topographic position, except on the fringes of the blast zone. For both fires and volcanic eruptions that create broad disturbance patterns, patches that re main can be considered as part of the biological legacy that contributes to the rate of ecosystem recovery. The critical variable may not be the size of a disturbance, but rather the mean distance of a series of random points within a disturbed area to an undisturbed patch. Such patches can be expected to amplify greatly the other forms of biological legacy that inevitably remain (Table 2 ).

\section{ENDURING IMPRINTS OF LIDS ON FOREST ECOSYSTEMS}

Over extended periods encompassing many episodes of disturbance, landscape-level patterns of disturbance susceptibility, controlled by the interaction of the disturbance, physiography, and biota, may lead to long-lasting patterns of species and ecosystem distribution that represent enduring im- 
prints of disturbance (Whitmore 1974; Foster and others 1999). This long-term landscape consequence of disturbance regimes has not been investigated extensively but may be a common effect of some LIDs due to their size and predictable distributions at a landscape scale (Smith 1946; Swanson and others 1988; Foster and Boose 1994). For fire, directionality of prevailing winds during the droughty fire season and the distribution of physiographic firebreaks may lead to a well-developed landscape pattern of frequency and intensity. Over repeated episodes, the landscape variation in disturbance regime may control forest distribution (Heinselman 1973), organic matter accumulation and wetland development (Foster 1983), and soil and ecosystem processes (Goodlett 1956; Viereck and others 1983) that in turn may have important feedbacks to the disturbance process (Grimm 1984; Foster and King 1986). In regions prone to catastrophic wind events, it has been suggested that persistent landscape-scale variation in site susceptibility may lead to important spatial variation in the frequency and intensity of damaging winds that over long periods may control canopy structure (Webb 1958; Lugo 1983), the distribution of understory plants (A. Sabato, personal communication), the spatial pattern and characteristics of successional and old-growth forests (Boose and others 1994), and primary production, hydrology, and nutrient retention (Swanson and others 1988; Scatena and others 1997). In all cases, these effects are not the consequence of individual events or sudden changes but the legacies of long-term predictability in the landscape distribution of a LID that has led to multiple outcomes and repeated patterns on similar sites.

\section{ACKNOWLEDGMENTS}

The development of the ideas in this report benefited greatly from the input of all members of the LIDs workshop held at the National Center of Ecological Analysis and Synthesis and supported by the National Science Foundation. Helpful comments were provided by $\mathrm{M}$. Turner, V. Dale, M. Tegner, W. Baker, P. Harcombe, T. Veblen, C. Canhan, and members of the Harvard Forest ecology group. Additional support was provided by the A. W. Mellon Foundation and Harvard Forest Long Term Ecological Research program (NSF-BSR9411764).

\section{REFERENCES}

AgeeJ K. 1993. Fire ecology of Pacific Northwest forests. Washington (DC): Island.
Anthes RA. 1982. Tropical cyclones: their evolution, structure and effects. American Meteorological Society, Boston: Meteorological Monographs 19.

Arno SF, Reinhardt ED, Scott JH. 1993. Forest structure and landscape patterns in the subalpine lodgepole pine type: a procedure for quantifying past and present conditions. Washington (DC): USDA Forest Service Intermountain Research Station; General Technical Report INT-924.

Baker VR, Kochel RC, Patton PC, editors. 1988. Flood geomorphology. New York: Wiley.

Bluestein HB. 1996. Tornadoes. In: Schneider SH, editor. Encyclopedia of climate and weather. Oxford: Oxford University Press, p 764-8.

Boose ER, Foster DR, Fluet M. 1994. Hurricane impacts to tropical and temperate forest landscapes. Ecol Monogr 64:369400.

Bormann H, Likens G. 1979. Pattern and process of a forest ecosystem. New York: Springer-Verlag.

Bornette G, Amoros C. 1997. Disturbance regimes and vegetation dynamics: role of floods in riverine wetlands. J Vegetation Sci 7:615-22.

Bowden R, Castro MC, Melillo J M, Steudler PA, Aber JD. 1993. Fluxes of greenhouse gases between soils and the atmosphere in a temperate forest following a simulated hurricane blowdown. Biogeochemistry 21:61-71.

Carlton GC, Bazzaz F. 1998. Resource congruence and forest regeneration following an experimental hurricane blowdown. Ecology 79:1305-19.

Christensen NL, Agee JK, Brussard PF, Hughes J, Knight DH, Minshall GW, Peek JM, Swanson FJ, Thomas JW, Wells S, Williams S, Wright HA. 1989. Interpreting the Yellowstone fires of 1988. BioScience 39:678-86.

Clark JS. 1989. Ecological disturbance as a renewal process: theory and application to fire history. Oikos 56:17-30.

Cooper-Ellis S, Foster D, Carlton G, Lezberg A. Forest response and reorganization following experimental hurricane. Ecology. Forthcoming.

Covich A, Crowl TA, Johnson SL, Pyron M. 1997. Distribution and abundance of tropical freshwater shrimp along a stream corridor: response to disturbance. Biotropica 28:484-92.

Dunn CP, Guntenspargen GR, Droney J R. 1983. Catastropic wind disturbance in an old-growth hemlock-hardwood forest, Wisconsin. Can J Bot 61:211-7.

Dunn GE, Miller BI. 1964. Atlantic hurricanes. Rev. ed. Baton Rouge: Louisiana State University Press.

Foster DR. 1983. The history and pattern of fire in the boreal forest of southeastern Labrador. Can J Bot 61:2459-71.

Foster DR. 1988a. Disturbance history, community organization and vegetation dynamics of the old-growth Pisgah Forest, southwestern New Hampshire, USA.J Ecol 76:105-34.

Foster DR. 1988b. Species and stand response to catastrophic wind in central New England, USA.J Ecol 76:135-51.

Foster DR, Aber J, Bowden R, Melillo J, Bazzaz F. 1997. Temperate forest response to catastrophic disturbance and chronic stress. BioScience 47:437-45.

Foster DR, Boose ER. 1992. Patterns of forest damage resulting from catastrophic wind in central New England, USA. J Ecol 80:79-98.

Foster DR, Boose ER. 1994. Hurricane disturbance regimes in temperate and tropical forest ecosystems. In: Coutts M, editor. Wind effects on trees, forests and landscapes. New York: Cambridge University Press. p 305-39. 
Foster DR, Fluet M, Boose ER. 1999. Natural or human disturbance: landscape dynamics of the tropical forests of Puerto Rico. Ecol Appl. Forthcoming.

Foster DR, King GA. 1986. Vegetation pattern and diversity in S.E. Labrador, Canada: Betula papyrifera (birch) forest development in relation to fire history and physiography. J Ecol 74:465-83.

Frank WM. 1977. The structure and energetics of the tropical cyclone. I. Storm structure. Mon Weather Rev 105:119-35.

Franklin J F, Hal pern CB. 1989. Influence of biological legacies on succession. In: Ferguson DE, Morgan P, J ohnson FD, editors. Proceedings: land classifications based on vegetation-applications for resource management. Washington (DC): USDA Forest Service, Intermountain Research Station. p 54-5.

Franklin JF, MacMahon JA, Swanson FJ, Sedell JR. 1985. Ecosystem responses to the eruption of Mount St. Helens. Nat Geogr Res 1:198-216.

Fujita TT. 1971. Proposed characterization of tornadoes and hurricanes by area and intensity. Chicago: Department of Geophysical Sciences, University of Chicago; Satellite and Mesometeorology Research Project Paper 91.

Fujita TT. 1987. U. S. Tornadoes: part one-70-year statistics. Chicago: University of Chicago Satellite and Mesometeorology Research Project.

Gara RT, Little WR, Agee J K, Geiszler DR, Stuart JD, Driver CH. 1984. Influence of fire, fungi and mountain pine beetles on development of a lodgepole pine forest in south-central Oregon. In: Lodgepole pine: the species and management. $\mathrm{p}$ 35-7.

Goodlett JC. 1956. Vegetation and surficial geology. In: Surficial geology and geomorphology of Pottern County, Pennsylvania.

Gray WM. 1990. Strong association between West African rainfall and US landfall of intense hurricanes. Science 249: 1251-6.

Grazulis TP. 1993. Significant tornadoes, 1680-1991. St. J ohnsbury (VT): Environmental Films.

Grimm EC. 1984. Fire and other factors controlling the Big Woods vegetation of Minnesota in the mid-nineteenth century. Ecol Monogr 54:291-311.

Harmon ME, Franklin JF, Swanson FJ, Sollins P, Gregory SV, Lattin JD, Anderson NH, Cline SP, Aumen NG, Sedell JR, Linekaemper GW, Cromack K J r, Cummins KW. 1986. Ecology of coarse woody debris in temperate ecosystems. In: MacFadyen A, Ford ED, editors. Advances in ecological research. Orlando (FL): Academic. p 133-302.

Heinselman ML. 1973. Fire in the virgin forests of the Boundary Waters Canoe Area, Minnesota. Quat Res (NY) 3:329-82.

Heinselman ML. 1996. The boundary waters wilderness ecosystem. Minneapolis: University of Minnesota Press.

Hemstrom MA, Franklin J F. 1982. Fire and other disturbances of the forests in Mount Rainier National Park. Quat Res (NY) 18:32-51.

Knight D. 1987. Parasites, lightning, and the vegetation mosaic in wildernesslandscapes. In: Turner MG, editor. Landscape heterogeneity and disturbance. New York: Springer-Verlag. p 59-83.

Lugo A. 1983. Ecological aspects of catastrophes in Caribbean Islands. Acta Cient 2:24-31.

Lugo AE, Scatena FN. 1989. Ecosystem properties of the Luquillo Forest of Puerto Rico. In: Proceedings of the ITF 50th anniversary symposium.

Lynch J F. 1991. Effects of Hurricane Gilbert on birds in a dry tropical forest in the Yucatan Peninsula. Biotropica 23:488-96.
Melanson GP, Butler DR. 1984. Avalanche paths as fuel breaks: implications for fire management. J Environ Manage 19: 229-38.

Motzkin G, Foster D, Allen A, Harrod J, Boone R. 1996. Controlling site to evaluate history: vegetation patterns of a New England sand plain. Ecol Monogr 66:345-65.

Naka K. 1982. Community dynamics of evergreen broadleaf forests in southwestern Japan. 1. Wind damaged trees and canopy gaps in an evergreen oak forest. Bot Mag Tokyo 95:385-99.

Paine RT, Tegner MJ , J ohnson EA. 1998. Compounded perturbations yield ecological surprises. Ecosystems 1:535-545.

Patterson WA, Foster DR. 1990. "Tabernacle Pines": the rest of the story. J For 89:23-5.

Peterken GF. 1997. Natural woodland: ecology and conservation in northern temperate regions. New York: Cambridge University Press.

Peterson CJ , Pickett STA. 1991. Treefall and resprouting following catastrophic windthrow in an old-growth, hemlockhardwood forest. For Ecol Manage 42:205-17.

Peterson CJ, Pickett STA. 1995. Forest reorganization: a case study in an old-growth forest catastrophic blowdown. Ecology 76:763-74.

Rogers P. 1996. Disturbance ecology and forest management: a review of the literature. Washington (DC): USDA Forest Service General Technical Report INT-GTR-336.

Scatena F, Larsen M. 1991. Physical aspects of Hurricane Hugo in Puerto Rico. Biotropica 23:317-23.

Scatena FN, Maya S, Estrada C, Chinea J. 1997. The first five years in the reorganization of aboveground biomass and nutrient use following HurricaneHugo in the Bisley Experimental Watersheds, Luquillo Experimental Forest, Puerto Rico. Biotropica 28:424-41.

Shaw WB. 1983. Tropical cyclones: determinants of pattern and structure in New Zealand's indigenous forests. Pac Sci 37: 405-14.

Simpson RH, Riehl H. 1981. The hurricane and its impact. Baton Rouge: Louisiana State University Press.

Smith DM. 1946. Storm damage in New England forests [MS thesis]. New Haven: Yale University. 173 pp.

Sparks RE. 1996. Ecosystem effects: positive and negative outcomes. In: Changnon SA, editor. The great flood of 1993. (CO): Westview. p 132-62.

Stephens EP. 1956. The uprooting of trees: a forest process. Soil Science Society proceedings. p 113-6.

Swanson FJ. 1981. Fire and geomorphic processes. In: Mooney $H A$, editor. Proceedings of the conference on fire regimes and ecosystems. Washington (DC): USDA General Technical Report.

Swanson FJ, Franklin JF, Sedell JR. 1990. Landscape patterns, disturbance, and management in the Pacific Northwest, USA. In: Zonneveld IS, Forman RTT, editors. Trends in landscape ecology. New York: Springer-Verlag. p 191-213.

Swanson FJ , Kratz TK, Caine N, Woodmansee RG. 1988. Landform effects on ecosystem patterns and processes. BioScience 38:92-8.

Turner MG, Dale VH. 1998. Comparing large, infrequent disturbances: what have we learned? Ecosystems 1:493-496.

Veblen TT, Kitzberger T, Lava A. 1992. Disturbance and forest dynamics along a transect from Andean rain forest to Patagonian shrubland. J Veg Sci 8:507-20. 
Viereck LA, Dyrness CT, Van Cleve K, Foote MJ . 1983. Vegetation soils and forest productivity in selected forest types in interior Alaska. Can J For Res 13:703-20.

Webb LJ. 1958. Cyclones as an ecological factor in tropical lowland forest, North Queensland. Aust] Bot 6:220-8.

Whelan RJ . 1995. The ecology of fire. Cambridge: Cambridge University Press.

Whitmore TC. 1974. Change with time and the role of cyclones in tropical rain forest on Kolombangara, Solomon Islands. Oxford: Holywell; Commonwealth Forestry Institute Paper 46.
Williams GP, Wolman MG. 1984. Downstream effects of dams on alluvial rivers. Washington (DC): United States Geological Survey; Professional Paper 1286.

Wood DM, Morris WF. 1990. Ecological constraints to seedling establishment on the Pumice Plains, Mount St. Helens, Washington. AmJ Bot :1411-8.

Yih K, Boucher D, Vandermeer J, Zamora N. 1991. Recovery of the rain forest of southeastern Nicaragua after destruction by Hurricane J oan. Biotropica 23:106-13.

Zimmermann J, Willig MR, Walker LR, Silver WL. 1997. Disturbance and Caribbean ecosystems. Biotropica 28:414-23. 